\title{
Development of E-Learning, Mobile Apps, Character Building, and Outdoor Study (EMCO Learning Model) to Improve Geography Outcomes in the 21st Century
}

\author{
https://doi.org/10.3991/ijim.v15i07.21553 \\ Hendri Prastiyono( ${ }^{(\mathbb{})}$ \\ Universitas Negeri Malang, Malang, Indonesia \\ SMA Wachid Hasyim 2 Taman, Sidoarjo, Indonesia \\ geo.whtamanegmail.com \\ Sugeng Utaya, Sumarmi, I Komang Astina \\ Universitas Negeri Malang, Malang, Indonesia \\ Saiful Amin \\ Universitas Islam Negeri Maulana Malik Ibrahim Malang, Malang, Indonesia \\ Universitas Negeri Malang, Malang, Indonesia \\ Muhammad Aliman \\ Universitas Negeri Malang, Malang, Indonesia
}

\begin{abstract}
This development study aims to 1) create a learning model that fuses e-learning, a mobile app, character building, and outdoor study and 2) determine the effectiveness of the EMCO learning model on student learning outcomes. This study uses a research and development design with the model of Dick and Carey. A product feasibility test is performed by the learning, media, and materials expert validators, and the product's effectiveness is tested by students. The data analysis includes descriptive statistics to determine the product feasibility and an independent sample t-test to determine the effectiveness of the learning model. The results of the expert validation show that the EMCO model is in the very good category and does not need revision. The EMCO model has a learning syntax with four phases: LKPD (student worksheet), assessment instrument, learning media, and teaching materials. Results indicate that the EMCO learning model is effective in improving geography learning outcomes. The model has the advantages of 1) effective and innovative material delivery; 2) easy-to-use navigation keys to access the material; 3) attractive design; 4) availability of CBT (computer-based test); and 5) online learning media that can be accessed anytime, anywhere, and under any conditions. The research has a positive impact on students and is able to transform them into $21^{\text {st }}$-century learning agents.
\end{abstract}

Keywords-Development, EMCO learning model, geography learning outcomes 


\section{Introduction}

Geography, as a subject taught in high school, has both teaching and learning challenges in the 21 st century. The skills that students need in the 21 st century include critical thinking, creativity, communication, and collaboration [1]. While in its implementation, 21st century learning needs digital learner activity [2], [3] and the cultivation of character education as the hallmark of learners [4]. Implementing digital learning activities and character education requires a learning model that provides learning experiences for students.

Learning experiences are obtained by integrating outdoor study with e-learning and mobile app models such as audio, video, animation, images, and text [5]. The functions of the menu in e-learning and mobile apps are very helpful in 21 st century learning. Empirically, the results of previous research show that mobile apps using Android as a learning medium can improve students' interest in learning and academic results [6]. Students in high school need to study materials that can be accessed anywhere and anytime. In addition, they need a hands-on practice that differentiates the concepts from real-world conditions. Therefore, it is important to develop a learning model that integrates outdoor study with e-learning and a mobile app.

Based on existing geography curricula, developing a learning model is necessary to meet the needs of 21 st-century education. Innovations in the development of geography learning models, in addition to improving learning outcomes, can also improve the skills needed in 21 st-century competition. These innovations should encourage students to be more active and help them understand concepts [7]. Geography learning models should be close to nature and improve students' abilities in their own time [8].

Learning with digital activities can be realized by implementing e-learning [9] and mobile apps [10]. Therefore, a learning model that combines e-learning, a mobile app, character building, and outdoor study is necessary. This will hereafter be referred to as the EMCO learning model, and it provides a geography learning experience for students (geo-visualization). Through outdoor study, students often engage in learning and this can increase positive relationships between teachers and students [11]. The outdoor study not only improves learning outcomes but also improves students' writing skills [7].

Research related to e-learning has been conducted [9], [12]-[15]. So, also the research on automobile-related learning studied [6], [10], [16]-[19]. Some studies have combined e-learning and mobile apps [5], [20]-[24]. However, research and development that strive to combine e-learning, a mobile app, and outdoor study to develop the character of students have not been widely conducted. This integrated development focuses on developing digital learning materials that are integrated with activities in the field. Geography emphasizes outdoor and experimental learning [25], [26]. The outdoor study can encourage students to solve real problems in the field, so the results of students' learning and their environmental awareness can be enhanced [4]. Therefore, research is needed to develop learning that integrates these themes.

This study is similar to previous developments regarding innovative integrated learning models [6], [12], [16], [18], [19], [27]-[29]. The effectiveness of the EMCO 
learning model on learning outcomes also has similarities to previous studies that support research on e-learning [9], [30]-[32], m-learning [17], [19], and outdoor study [7], [11], [33], [34]. The difference in previous developments is that the EMCO model includes a character-building component. The characteristics of love for the country and concern for the environment are increased by including character building in the development model.

Based on these studies, this research aims to 1) develop a learning model that combines e-learning, a mobile app, character building, and outdoor study and 2) test the effectiveness of the product as a learning model on high school students to determine its effect on geography learning outcomes. The benefits of research being conducted change student-centered learning. Students are free to explore objects and teaching materials to find and develop concepts of understanding. The results of the study indicate a positive impact on students, namely, being able to implement increased learning abilities into life in the environment where they live. Students can transform this into 21 st-century learning agents.

\section{Method}

\subsection{Research design}

Research and development of the EMCO learning model used Dick and Carey [35]. The model was selected because it is (1) flexible and capable, that is, this model can be modified as long as it is not missing its main component, (2) systematic, meaning that it is composed of successive steps to minimize the weaknesses of a product, and (3) adaptive, meaning that it can be used in a variety of fields, including education. The procedure to develop the EMCO learning model uses Dick and Carey's model modified to be four categories, namely, requirements analysis, product development, product testing, and product revision.

The design of the trials is used to determine the effectiveness of the product using a quasi-experimental with non-equivalent control group design. The quasi-experimental design in this study is shown in Table 1.

Table 1. Quasi-Experimental Design

\begin{tabular}{|l|c|c|c|}
\hline \multicolumn{1}{|c|}{ Class } & Pretest & Treatment & Posttest \\
\hline Experimental & $\mathrm{O}_{1}$ & $\mathrm{X}_{1}$ & $\mathrm{O}_{2}$ \\
\hline Control & $\mathrm{O}_{3}$ & $\mathrm{X}_{2}$ & $\mathrm{O}_{4}$ \\
\hline
\end{tabular}

Information:

$\mathrm{O} 1$ and $\mathrm{O} 3=$ pretest

$\mathrm{O} 2$ and $\mathrm{O} 4=$ posttest

$\mathrm{X} 1$ = treatment with EMCO model

$\mathrm{X} 2$ = treatment with conventional model 


\subsection{Participants}

The development product feasibility test was conducted by the validator of learning experts, media, material geography, and students. Tests on the students were done in several stages, including small group tests consisting of 10 students and a large group test consisting of 46 students.

Subjects in the trial of the EMCO learning model's effectiveness on the learning outcomes of the students include the class XI IPS of SMA Wachid Hasyim 2 Taman, Indonesia academic year 2019-2020. Determining the experimental and control groups was done based on the technique of purposive sampling based on academic ability, which is almost the same. It was concluded that the experimental group was XI IPS 1 and XI IPS 2 up to 46 students, and the control group was XI IPS 3 and XI IPS 4 up to 46 students. Students in the experimental group used the EMCO learning model, and students in the control group used conventional learning models, including the lecture method, student presentations, and group discussions.

\subsection{Instruments and Data collection}

Data on the feasibility of the product is both qualitative and quantitative. Qualitative data include questionnaire responses obtained from learning experts and students. The quantitative data include the questionnaire scores of the validator experts (learning experts, media, and materials) and the students. The questionnaire was scored using a Likert scale with values of 1 (Yes) and 0 (No.) The questionnaire is comprised of 32 statements about e-learning, mobile apps, character building, and outdoor study. The questionnaire has been administered to test the validity by product moment shows the results of a valid (average count $=0.3233$ ). Furthermore, a reliability test by Cronbach's alpha shows reliable results (alpha $=0.691)$.

Quantitative data on the effectiveness of the development product include the results of the pretest and posttest. Data on student learning outcomes were collected by administering an evaluation test with 10 choice questions and an essay test consisting of five questions. The assessments have been done to test the validity by product moment shows the results of valid (average count $=0.4883$ ). A reliability test using Cronbach's alpha shows that the results are reliable (alpha $=0.722$ ).

\subsection{Data analysis}

Data on the feasibility of the development product were analyzed by using quantitative descriptions to identify the percentage score of the responses from the expert validators and students. An analysis of descriptive statistics uses the following formula [36]:

$$
\text { Percentage }(\%)=\frac{\sum(\text { total of questionnaire answers })}{\mathrm{N} \times \mathrm{n} \times \text { the highest score }} \times 100 \%
$$

Furthermore, determining the feasibility of the development product is based on the criteria presented in Table 2 [36]. 
Paper—Development of E-Learning, Mobile Apps, Character Building, and Outdoor Study...

Table 2. Table 2. Eligibility Criteria of Development Product

\begin{tabular}{|c|l|l|}
\hline Criteria & \multicolumn{1}{|c|}{ Category } & \multicolumn{1}{c|}{ Conclusion } \\
\hline$\geq 91 \%$ & Very Good & No revision \\
\hline$\geq 71 \%-<91 \%$ & Good & No revision \\
\hline$\geq 51 \%-<71 \%$ & Quite Good & Revision \\
\hline$<51 \%$ & Not Good & Revision \\
\hline
\end{tabular}

Data on the effectiveness of the EMCO model based on the results of the study were analyzed using a normality test, homogeneity test, and independent sample ttest. The t-test analysis was done using SPSS 21.00 for Windows with a significance level of $5 \%$. The hypothesis of this research is as follows:

H0: There is no difference between the learning outcomes of students who applied the EMCO learning model and students who applied conventional learning.

H1: There are differences between the learning outcomes of students who applied the EMCO learning model and students who applied conventional learning.

Determination:

If $\mathrm{HO}>$ significance 0.05 , then $\mathrm{H} 0$ is accepted.

If $\mathrm{HO}<$ significance 0.05 , then $\mathrm{H} 0$ is rejected.

\section{Results and Discussion}

\subsection{Development product of the EMCO learning model}

The development product is used as a model of innovative learning in the classroom. Teachers and students can use the product by accessing online learning media on www.schoology.com (Figure 1) through a computer, laptop, or smartphone. The development product includes syntax learning, student worksheets, a process assessment instrument, media, and e-learning teaching materials (Figure 2). 


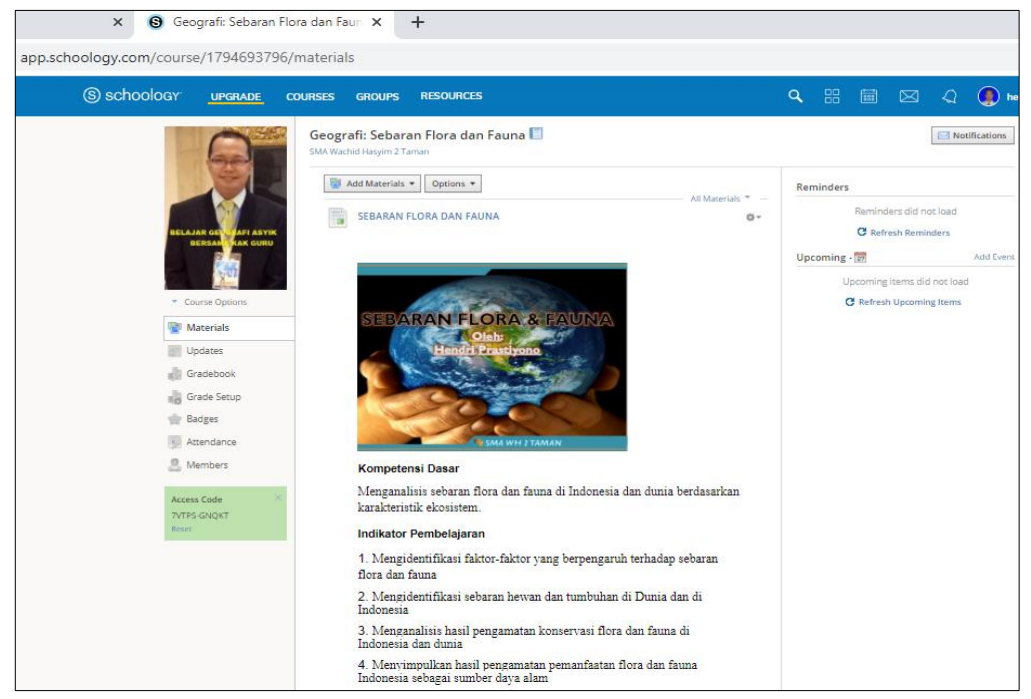

Fig. 1. E-Learning Dashboard Using Schoology

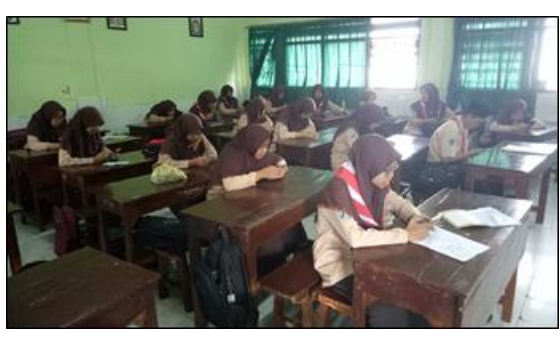

a)

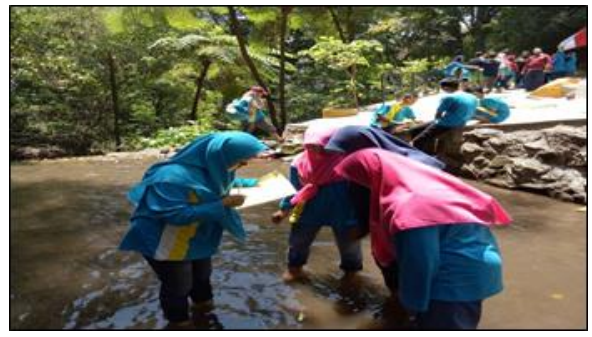

c)

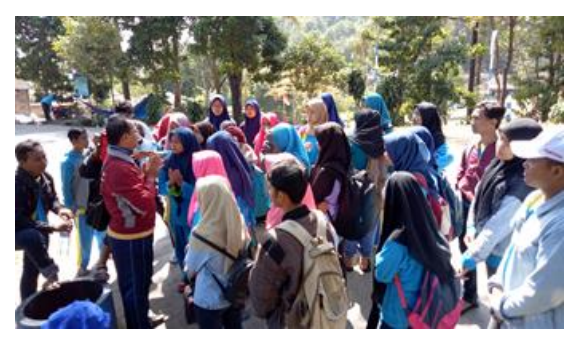

b)

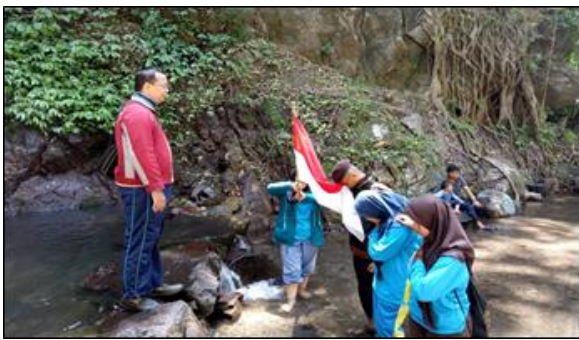

d)

Fig. 2. Preparation with m-learning (a), Directing outdoor activities (b), Students work on the worksheet (c), and Character-Building Activities for Environment Care (d) 
The product of the results is the EMCO learning model, which was qualitatively improved with the help of learning experts, media, and materials validators. Feedback from learning experts includes 1 ) add a description of the activities for teachers so the learning steps are easy for other teachers to apply; 2) ensure the model can sync with the newest curriculum in which students are the center of learning; 3) the syntax must contain 21st-century learning skills, namely, 4C, literacy, and character education; and 4) outdoor learning should focus on finding and analyzing the problems, then making a conclusion or solving the problem. The syntax of the revised EMCO learning model is shown in Table 3.

Table 3. The Syntax of the EMCO Learning Model

\begin{tabular}{|c|c|}
\hline \multirow{2}{*}{$\begin{array}{l}\text { Phase } 1 \text { : Digital } \\
\text { literacy and } \\
\text { planning studies } \\
\text { as well as } \\
\text { preparation of } \\
\text { necessary things } \\
\text { (pre-trip) }\end{array}$} & $\begin{array}{l}\text { Teachers discuss the purpose of the lesson, invite students to read materials } \\
\text { through e-learning and the mobile app, describe various logistics needs, and } \\
\text { motivate students to engage in activities such as travel around the neighborhood. }\end{array}$ \\
\hline & $\begin{array}{l}\text { Students read the material through the e-learning and mobile app, and then } \\
\text { they develop the logistics and prepare for the trip in groups. }\end{array}$ \\
\hline \multirow{2}{*}{$\begin{array}{l}\text { Phase } 2 \text { : Embark } \\
\text { on a journey of } \\
\text { field study and } \\
\text { find meaning (on } \\
\text { trip) }\end{array}$} & $\begin{array}{l}\text { Teachers explore the surrounding environment, make a trip at some point to } \\
\text { observe, connect the concepts to the real world, make observations, and interpret } \\
\text { the object of observation through character cultivation. }\end{array}$ \\
\hline & $\begin{array}{l}\text { Students explore the environment using the guide from the teacher and make } \\
\text { observations using the worksheet in the application. }\end{array}$ \\
\hline \multirow{2}{*}{$\begin{array}{l}\text { Phase } 3 \text { : Suggest } \\
\text { retrospect (after } \\
\text { trip) }\end{array}$} & $\begin{array}{l}\text { The teacher encourages students to recall the trip and look for an explanation } \\
\text { according to the available concepts. }\end{array}$ \\
\hline & $\begin{array}{l}\text { Students retell the facts and relate the concepts of their findings during the } \\
\text { trip. }\end{array}$ \\
\hline \multirow{2}{*}{$\begin{array}{l}\text { Phase } 4 \text { : Analyze, } \\
\text { solve problems, } \\
\text { and draw } \\
\text { conclusions } \\
\text { (decision-making) }\end{array}$} & $\begin{array}{l}\text { Teachers help students plan and prepare appropriate artifacts to be analyzed } \\
\text { (such as reports, video recordings, and photos), and then draw a red thread to the } \\
\text { problems to be solved. Last, draw conclusions. }\end{array}$ \\
\hline & $\begin{array}{l}\text { Students analyze the data then create a report that includes problem solving } \\
\text { results and conclusions. }\end{array}$ \\
\hline
\end{tabular}

The syntax of the EMCO learning model has four phases: (1) Pre-Trip, which includes preparing by digital literacy and planning field studies. In this first phase of the activity, students act as designers and teachers provide input on existing designs. The first phase is crucial in determining the next learning step because poor planning and a lack of preparation will hamper the next phase. The students and teacher should be able to briefly review the results of the first phase. (2) Trip is the second phase, and it includes a field study trip and meaningful learning. Activities in this second phase are student-centered to find and form the concept of understanding objects in the field. The teacher provides a portion of input and direction to create a conceptual frame- 
work. This phase usually requires patience and takes some time. (3) After Trip, the third phase includes the results obtained by the students, learning retention, and teacher input in developing concepts. This phase can be done in class after the field studies. In this phase, students must communicate well to help other students understand. (4), Decision-making is the final and most important phase in the EMCO learning model. This includes implementation in the form of solving problems encountered during trips and debriefs. Understanding the concept and enhancing the characteristics of love for the country and caring for the environment can be seen at this phase. Learning retention will also be visualized into a meaningful learning experience.

Media experts provided feedback: 1) learning should be presented in a simple and systematic framework in the form of an e-module so it is easily accessible to students; 2) artificial media used in biosphere learning - like a map of the flora and fauna distribution - should be developed by the students instead of the teacher; and 3) teachers should strengthen the repertoire of media knowledge created by students. The results of the media revision can be seen in Figure 3 (a).

Feedback was also provided by material experts: 1) characteristics of the biosphere material in geography lessons should include more concrete concepts, so it needs both direct and indirect experience; 2) a student worksheet is needed to understand the material clearly; 3) the student worksheet should include the assessment instruments of cognitive, affective, and process; 4) on the biosphere material, a conceptual framework of e-learning in the form of a PowerPoint is needed so students can easily learn them; and 5) the biosphere material should include character education that can be established through an environmental approach during outdoor study. The revisions of the material can be seen in figures 3 (b) and (c).

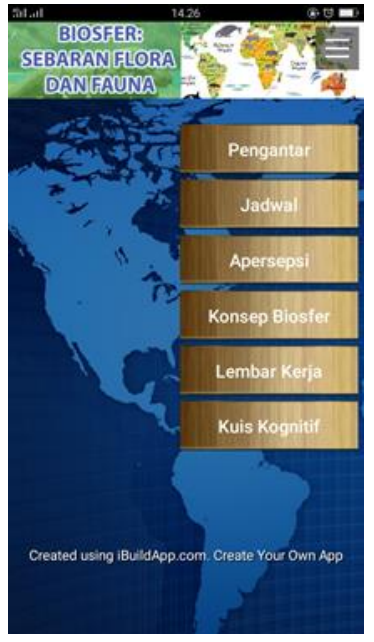

a) Material of the biosphere

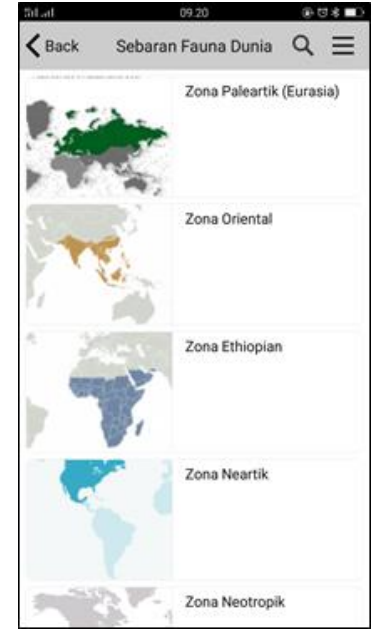

b) Student worksheet

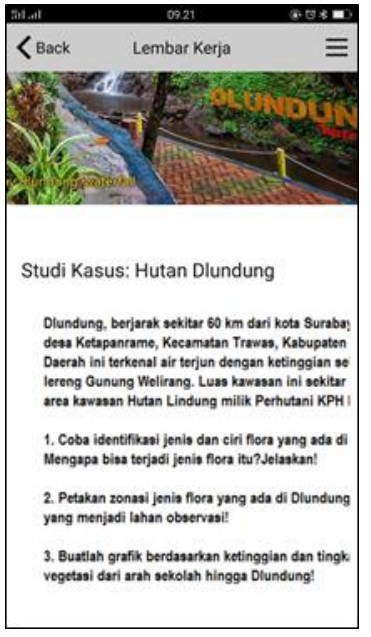

c) Student worksheet

Fig. 3. The appearance of e-learning 
Product testing is done after the revision process suggested by the learning, media, and materials expert validators. The field tests of students in small and large groups is then performed. Field tests were done in three stages (Figure 2), namely: (1) elearning study, (2) outdoor learning study using a mobile app, and (3) integration of character in the learning process. A recapitulation of the test results of all respondents to the EMCO learning model can be seen in Table 4.

Table 4. A Recapitulation of the Test Results of All Respondents

\begin{tabular}{|c|l|c|l|l|}
\hline No. & \multicolumn{1}{|c|}{ Correspondent } & Percentage $(\boldsymbol{\%})$ & \multicolumn{1}{c|}{ Category } & \multicolumn{1}{c|}{ Conclusion } \\
\hline 1. & Learning expert & 88.00 & Good & No revision \\
\hline 2. & Media expert & 91.00 & Very Good & No revision \\
\hline 3. & Geographical materials expert & 85.00 & Good & No revision \\
\hline 4. & Small group trials & 94.69 & Very Good & No revision \\
\hline 5. & Large group trials & 91.03 & Very Good & No revision \\
\hline Average & 89.94 & Good & No revision \\
\hline
\end{tabular}

As shown in Table 4, the results of the assessment test of the EMCO learning model is $89.94 \%$. This suggests that models of the development product are within the category of very good and do not need revision, so it can be concluded that the EMCO learning model has met the feasibility standard to be used in geography learning.

\subsection{The Effectiveness of the EMCO learning model compared to learning outcomes}

A comparison of the data about the learning outcomes of experimental and control groups in this study can be seen in Figure 4. The learning results in Figure 4 show that the average student learning outcomes in the experimental group, before and after using the EMCO learning model, went from 40.78 to 84.37 , which is an increase of 43.59. Furthermore, the average learning outcomes of students in the control group before and after using the conventional model went from 41.06 to be 66.80 , which is an increase of 25.74. Based on the improved scores, both groups showed the presence of increased learning outcomes. The conclusion is that the ECMO learning model was able to improve students' learning outcomes more than the conventional model. 


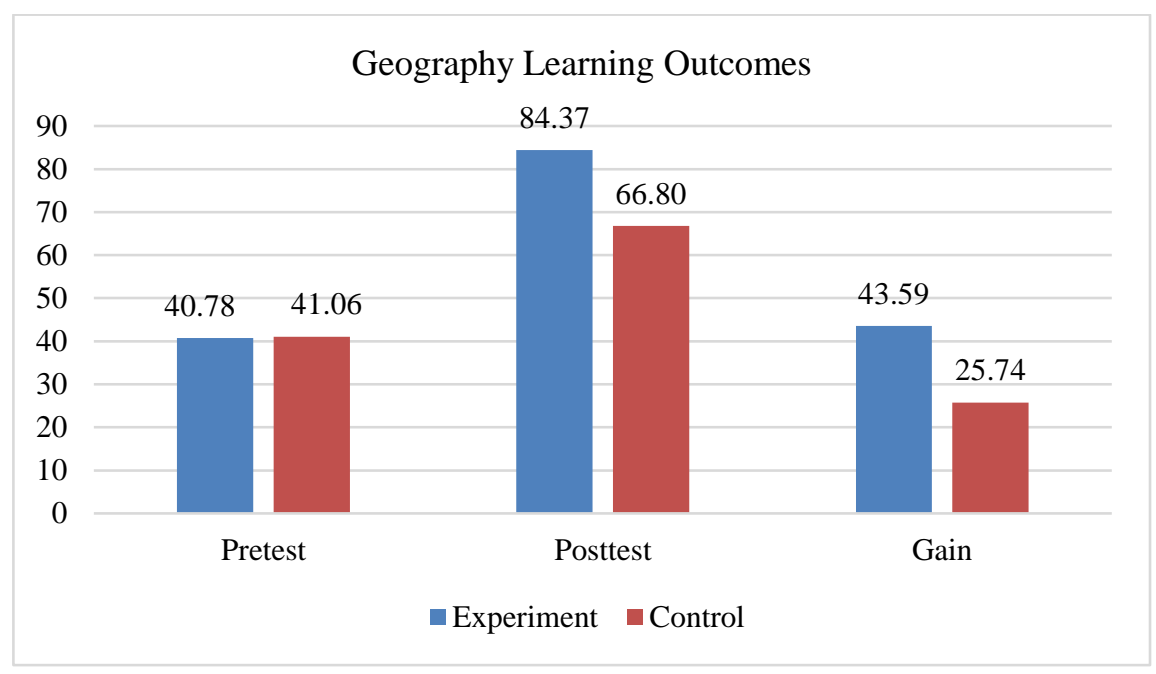

Fig. 4. Data on Geography Learning Outcomes

Furthermore, the results of the study data were tested for effectiveness by using an independent sample t-test that had previously been done through a normality (Table 5) and homogeneity test (Table 6).

Table 5. Normality Test

\begin{tabular}{|l|c|c|c|}
\hline \multirow{2}{*}{\multicolumn{2}{|c|}{ Group }} & \multicolumn{3}{c|}{ Kolmogorov-Smirnov $^{\mathbf{a}}$} \\
\cline { 2 - 4 } & Statistic & $\boldsymbol{d f}$ & Sig. \\
\hline Experimental & .152 & 46 & .100 \\
\hline Control & .095 & 46 & .200 \\
\hline
\end{tabular}

Table 6. Homogeneity Test

\begin{tabular}{|c|c|c|c|}
\hline Levene Statistic & df1 & df2 & Sig. \\
\hline .109 & 7 & 90 & .742 \\
\hline
\end{tabular}

Based on Table 5, sig. $0.100>0.050$ for the experimental group and $0.200>0.050$ for the control group were obtained, so the results of this study are normally distributed. Table 6 shows that the value of sig. $0.742>0.050$, so it can be concluded that the results of learning in both groups have a homogeneous variant. Furthermore, a test on the difference in learning outcomes in the form of gain scores between the experimental and controlled groups was performed, and the results are shown in Table 7. 
Paper-Development of E-Learning, Mobile Apps, Character Building, and Outdoor Study...

Table 7. Test Results of Independent Sample t-Test

\begin{tabular}{|c|c|c|c|c|c|c|}
\hline \multicolumn{7}{|c|}{ t-Test for Equality of Means } \\
\hline \multirow[t]{2}{*}{$t$} & \multirow[t]{2}{*}{$d f$} & \multirow{2}{*}{$\underset{\text { (2-tailed) }}{\text { Sig. }}$} & \multirow[t]{2}{*}{ Mean Difference } & \multirow{2}{*}{$\begin{array}{l}\text { Std. Error } \\
\text { Difference }\end{array}$} & \multicolumn{2}{|c|}{$\begin{array}{l}\text { 95\% Confidence Interval of the } \\
\text { Difference }\end{array}$} \\
\hline & & & & & Lower & Upper \\
\hline 3.454 & 90 & .001 & 10.60870 & 3.07120 & 4.50722 & 16.71017 \\
\hline 3.454 & 89.980 & .001 & 10.60870 & 3.07120 & 4.50720 & 16.71019 \\
\hline
\end{tabular}

The results of the t-test in Table 7 show sig. value $0.001<0.050$, which can be interpreted as a rejection of $\mathrm{H} 0$, and it can be concluded that there are differences between the learning outcomes of students who applied the EMCO learning model and conventional learning. The development product of the EMCO learning model is effective in improving geography learning outcomes.

The results of this study are in line with previous research on the development of learning models that are appropriate to use in learning [6], [12], [16], [18], [27]-[29], [37], [38]. The effectiveness of the EMCO learning model based on the results of the study also has similarities with previous research on e-learning [9], [30]-[32], mlearning [17], [19], and outdoor study [7], [33], [34], [39]. The difference between this study and previous research is the integration of the character-building component of the EMCO model. The characteristics of loving one's homeland and concern for the environment are increased by including character building in the development model.

The development of the EMCO model that is applied to the high school biosphere material has its advantages. Some advantages of the EMCO learning model: 1) the delivery of innovative and effective topics to help students' understanding; 2) the ease of a navigation key to access more in-depth topics according to the needs of students; 3) an attractive appearance and design improves students' motivation to learn; 4) is presented based on CBT (computer-based test) so that students can directly evaluate the learning that has occurred; and 5) online learning media that can be accessed anytime, anywhere, and under any conditions. The strengths of the product support improving geography learning outcomes for high school students.

In addition to having advantages, the product also has weaknesses in e-learning and mobile app learning. E-learning should have a containment system at the learning stage so that students can follow the learning flow. The learning flow at each stage can be controlled through an e-learning system such as the Moodle application. The weakness of the retaining system in Schoology allows students to explore learning material not in a continuous and systematic manner. On the mobile app, there is no glossary, so if students do not understand a term, they have no way to look it up on the app. According to respondents, a glossary is needed to accelerate the application interface.

The improvement of learning outcomes in the experimental group that applied the EMCO learning model in small group and large group trials was influenced by the ability of the students in the field of information and technology. Students with good computer and internet skills tended to improve learning outcomes [40]. On this basis, assessing the quality of the website is also good. This is motivated by the intensity of 
browsing, which is quite high, so they get used to the display reading on the internet. This kind of perception causes a fond feeling when reading teaching materials on the web [20], [41], [42].

Furthermore, the success of the EMCO model is influenced by the facilities and infrastructure in the form of the internet network. A good internet network influences the quality of the web view [30], [43]-[45]. The web will perform perfectly if it is accessed by a strong internet network; on the contrary, if the network is weak, then the web view will be difficult for students to access. This research conducted trials on a small group in a school that has a good internet network. Furthermore, the large group trial is performed at the place of residence of each student with a good quality internet because most students reside in urban areas.

In addition, the means used to access also affects the appearance of the website [46]-[49] because of the difference between the desktop and the mobile versions. In classroom learning, students use a computer so that the web view looks perfect. During outdoor learning, students use a mobile phone, so it is viewed on the mobile version. Therefore, the role of the teacher in the field becomes important as a facilitator to explain to the students what is related to the material understanding in the application.

The success of the EMCO learning model was also caused by the characteristics of the geography science subjects, in particular, the material of the biosphere. The biosphere material brings a logical consequence in the implementation of learning inside and outside the classroom. The biosphere material cannot be taught only by transferring knowledge through the lecture method or question and answer. Rather, it should be taught based on approach-oriented learning on the scientific process with experimental methods. The scientific skills in geography are oriented to a process skill approach. Process skills include observation, classification, interpretation, prediction, questioning, forming a hypothesis, experimentation, and communication [50]. A process owned by students supports improved geography learning outcomes.

\section{Conclusion and Suggestions}

The results of this study indicate that the product, which is specialized in the EMCO learning model, is feasible to use in geography learning. The value of worthiness is $89.94 \%$, included in both categories. The development product is in the form of the EMCO learning model consisting of the syntax study with four phases: LKPD (student worksheet), process assessment instrument, learning media, and e-learning teaching materials. Second, the EMCO learning model effectively improved the learning outcomes of high school geography students. The significance value of the t-test is 0.001 , which is smaller than the significance of $5 \%$. Recommendations for further studies include doing a research experiment or classroom action research to determine the effect or improvement of the EMCO learning model with other variables such as student interest and learning achievement in different subjects and schools. For those using the learning model, recommendations are that the outdoor activities should be done in a place that has a network or strong internet access; small groups should be 
formed so that students can participate in discussions, share, explain, and defend ideas, and give feedback on other students' ideas; and knowledge about how to use the tool (such as measuring techniques and data communication) should be provided in advance.

\section{$5 \quad$ References}

[1] M. Bialik and C. Fadel, Skills for the 21st Century: What Should Students Learn? Boston: Montes Alti Educational Foundation, 2015.

[2] J. Voogt, O. Erstad, C. Dede, and P. Mishra, "Challenges to Learning and Schooling in the Digital Networked World of The 21st Century," Journal of Computer Assisted Learning, vol. 29, no. Special Issue, Art. no. Special Issue, Oct. 2013, https://doi.org/10.1111/ jcal.12029.

[3] H. Boholano, "Smart Social Networking: 21st Century Teaching and Learning Skills," Research in Pedagogy, vol. 7, no. 1, Art. no. 1, Jun. 2017, https://doi.org/10.17810/2015.45.

[4] S. Amin, S. Utaya, S. Bachri, S. Sumarmi, and S. Susilo, "Effect of Problem Based Learning on Critical Thinking Skill and Enviromental Attitude," Journal for the Education of Gifted Young Scientists, vol. 8, no. 2, Art. no. 2, Jun. 2020, https://doi.org/10.17478/jeg ys.650344.

[5] S. K. Behera, "E- And M-Learning: A Comparative Study," International Journal on New Trends in Education and Their Implications, vol. 4, no. 3, pp. 65-78, 2013.

[6] T. S. Handayani and S. Suharyanto, "Pengembangan Mobile Learning Berbasis Android Sebagai Media Pembelajaran Pada Materi Fluida Statis Untuk Meningkatkan Minat Dan Hasil Belajar Ranah Kognitif Peserta Didik," E-Journal Pendidikan Fisika, vol. 5, no. 6, Art. no. 6, Jun. 2016, Accessed: Jul. 27, 2020. [Online]. Available: http://journal.student. uny.ac.id/ojs/index.php/pfisika/article/view/1957. https://doi.org/10.31219/osf.io/typmc

[7] Ach. Fatchan, H. Soekamto, S. Sumarmi, and S. Utaya, "Effect of Learning 'Outdoor Study' Ability to Communicate in Writing and Social-Geography Student Learning Outcomes at 'Mataraman' East Java-The Republic of Indonesia," Mediterranean Journal of Social Sciences, vol. 7, no. 3, pp. 429-435, May 2016, https://doi.org/10.5901/mjss.2016. v7n3p429.

[8] Sumarmi, Model-Model Pembelajaran Geografi. Malang: Aditya Media Publishing, 2015.

[9] O. O. Jethro, A. M. Grace, and A. K. Thomas, "E-Learning and Its Effects on Teaching and Learning in a Global Age," International Journal of Academic Research in Business and Social Sciences, vol. 2, no. 1, p. 8, 2012.

[10] [10] R. Cobcroft, S. Towers, J. Smith, and A. Bruns, "Mobile Learning in Review: Opportunities and Challenges for Learners, Teachers, and Institutions," in Proceedings Online Learning and Teaching (OLT), Brisbane, 2008, pp. 21-30.

[11] E. Fägerstam, "Space and Place : Perspectives on outdoor teaching and learning," Dissertation, Linköping University, Linköping, 2012.

[12] P. Pratama, "Pengembangan Pembelajaran E-learning Berbasis Moodle pada Materi Pedosfer Kelas X Sekolah Menengah Atas.” Pascasarjana Universitas Negeri Malang, 2011.

[13] J. Eklund, M. Kay, and H. M. Lynch, "E-Learning: Emerging Issues and Key Trends." Australian Flexible Learning Framework, 2017.

[14] M. Coopasami, S. Knight, and M. Pete, "E-Learning Readiness Amongst Nursing Students at the Durban University of Technology," Health SA Gesondheid, vol. 22, pp. 300-306, Dec. 2017, https://doi.org/10.1016/j.hsag.2017.04.003.

[15] V. Arkorful and N. Abaidoo, "The role of e-learning, the advantages and disadvantages of its adoption in Higher Education.," International Journal of Education and Research, vol. 2, no. 12, Art. no. 12, 2014. 
[16] H. Mabruri, F. Ahmadi, and T. Suminar, "The Development of Science Mobile Learning Media to Improve Primary Students Learning Achievements," 1, vol. 8, no. 1, Art. no. 1, 2019.

[17] M. R. D. Saputra and H. Kuswanto, "The Effectiveness of Physics Mobile Learning (PML) with HomboBatu theme to Improve the Ability of Diagram Representation and Critical Thinking of Senior High School Students," International Journal of Instruction, vol. 12, no. 2, Art. no. 2, Apr. 2019, https://doi.org/10.29333/iji.2019.12230a.

[18] S. S. Oyelere, J. Suhonen, G. M. Wajiga, and E. Sutinen, "Design, Development, and Evaluation of a Mobile Learning Application for Computing Education," Educ Inf Technol, vol. 23, no. 1, Art. no. 1, Jan. 2018, https://doi.org/10.1007/s10639-017-9613-2.

[19] M. Sarrab, M. Elbasir, and S. Alnaeli, "Towards a Quality Model of Technical Aspects for Mobile Learning Services: An Empirical Investigation," Computers in human behavior, vol. 55, pp. 100-112, Feb. 2016, https://doi.org/10.1016/j.chb.2015.09.003.

[20] D. Najima and A. Rachida, "An Adaptation of E-learning Standards to M-learning," International Journal of Interactive Mobile Technologies (iJIM), vol. 2, no. 3, p. 6, 2008.

[21] A. T. Korucu and A. Alkan, "Differences between m-learning (mobile learning) and elearning, basic terminology and usage of m-learning in education," Procedia - Social and Behavioral Sciences, vol. 15, pp. 1925-1930, Jan. 2011, https://doi.org/10.1016/j.sbspro. 2011.04.029.

[22] D. Balaji, F. A. Al-Mahri, and M. Balaji, "A Perspective Study on Content Management in E- Learning and M-Learning," Computer Science, p. 7, 2016.

[23] S. K. Basak, M. Wotto, and P. Bélanger, "E-learning, M-learning and D-learning: Conceptual definition and comparative analysis," E-Learning and Digital Media, vol. 15, no. 4, pp. 191-216, Jul. 2018, https://doi.org/10.1177/2042753018785180.

[24] R. Zouhair, B. lahmar El habib, and T. Abderrahim, "A Brief Survey and Comparison of m-Learning and e-Learning," Int. j. comput. netw. commun. secur., vol. 4, no. 4, pp. 8995, 2016.

[25] M. Aliman, Budijanto, Sumarmi, I. K. Astina, R. E. Putri, and M. Arif, "The Effect of Earthcomm Learning Model and Spatial Thinking Ability on Geography Learning Outcomes," JBSE, vol. 18, no. 3, Art. no. 3, Jun. 2019, https://doi.org/10.33225/jbse/19.18.3 $\underline{23}$.

[26] Sumarmi, S. Bachri, L. Yuda Irawan, D. B. Perdana Putra, Risnani, and M. Aliman, "The Effect of Experiential Learning Models on High School Students Learning Scores and Disaster Countermeasures Education Abilities," Journal for the Education of Gifted Young Scientists, vol. 8, no. 1, Art. no. 1, Mar. 2020, https://doi.org/10.17478/jegys.635632.

[27] N. Aeni, T. Prihatin, and Y. Utanto, "Pengembangan Model Blended Learning Berbasis Masalah pada Mata Pelajaran Sistem Komputer," Innovative Journal of Curriculum and Educational Technology (IJCET), vol. 6, no. 2, Art. no. 2, 2017.

[28] G. Amirullah and R. Hardinata, "Pengembangan Mobile Learning Bagi Pembelajaran," JKKP, vol. 4, no. 02, Art. no. 02, Oct. 2017, https://doi.org/10.21009/jkkp.042.07.

[29] E. D. Lestaringsih, "Pengembangan Model Problem Based Learning dan Blended Learning dalam Pembelajaran Pemantapan Kemampuan Profesional Mahasiswa," Jurnal Bahasa, Sastra, dan Budaya (LITE), vol. 13, no. 2, Art. no. 2, 2017. https://doi.org/10.17977/um0 $15 \mathrm{v} 45 \mathrm{i} 22017 \mathrm{p} 197$

[30] S. Abou El-Seoud, N. Seddiek, I. Taj-Eddin, P. Ghenghesh, A. Nosseir, and M. El-Khouly, "E-Learning and Students' Motivation: A Research Study on the Effect of E-Learning on Higher Education,” Int. J. Emerg. Technol. Learn., vol. 9, no. 4, Art. no. 4, Jun. 2014, https ://doi.org/10.3991/ijet.v9i4.3465.

[31] A.-M. Nortvig, A. K. Petersen, and S. H. Balle, "A Literature Review of the Factors Influencing E-Learning and Blended Learning in Relation to Learning Outcome, Student Satisfaction and Engagement," JEL, vol. 16, no. 1, Art. no. 1, 2018. 
[32] D. Üzel and E. Özdemir, "The Effects of Problem-Based E-Learning on Prospective Teachers' Achievements and Attitudes towards Learning Mathematics," Procedia - Social and Behavioral Sciences, vol. 55, pp. 1154-1158, Oct. 2012, https://doi.org/10.1016/ j.sbspro.2012.09.609.

[33] Harini, "Pengaruh Pembelajaran Tugas Kelompok Berdasarkan Survei Lapangan (Outdoor Study) terhadap Kemampuan Menulis Karya Ilmiah dan Hasil Belajar Siswa," Jurnal Penelitian Pendidikan, vol. 22, no. 1, Art. no. 1, 2012. https://doi.org/10.36456/bp.vol11. no20.a1353

[34] G. Maulidiyahwarti, Sumarmi, and Ach. Amirudin, "Pengaruh Model Problem Based Learning Berbasis Outdoor Study Terhadap Hasil Belajar Siswa Kelas XI IIS SMA," Jurnal Pendidikan: Teori, Penelitian, dan Pengembangan, vol. 1, no. 2, Art. no. 2, 2016. https://doi.org/10.26740/jrpd.v2n1.p84-91

[35] W. Dick and L. Carey, The Systematic Design of Intruction. Illinois: Scott Foresman and Company, 2001.

[36] S. Arikunto, Prosedur Penelitian: Suatu Pendekatan Praktik, 14th ed. Jakarta: Rineka Cipta, 2010.

[37] N. R. Akbarini, W. Murtini, and A. N. Rahmanto, "Design of Interactive Learning Multimedia Development in General Administration Subject," International Journal of Multicultural and Multireligious Understanding, vol. 5, no. 4, Art. no. 4, May 2018, https://doi.org/ 10.18415/ijmmu.v5i4.218.

[38] M. Sarrab, H. A. Shihi, B. Al-Manthari, and H. Bourdoucen, "Toward Educational Requirements Model for Mobile Learning Development and Adoption in Higher Education," TechTrends, vol. 62, no. 6, Art. no. 6, Nov. 2018, https://doi.org/10.1007/s11528-0180331-4.

[39] E. Fägerstam, "Space and Place : Perspectives on outdoor teaching and learning," Dissertation, Linköping University, Linköping, 2012. https://doi.org/10.1504/ijmlo.2014.067029

[40] C. L. Lai and G. J. Hwang, "Effects of mobile learning time on students' conception of collaboration, communication, complex problem-solving, meta-cognitive awareness and creativity," IJMLO, vol. 8, no. 3/4, p. 276, 2014, doi: 10.1504/IJMLO.2014.067029.

[41] H. F. El-Sofany, S. A. El-Seoud, H. M. Alwadani, and A. E. Alwadani, "Development of Mobile Educational Services Application to Improve Educational Outcomes using Android Technology," Int. J. Interact. Mob. Technol., vol. 8, no. 2, p. 4, Apr. 2014,. https://doi. org/10.3991/ijim.v8i2.3509

[42] S. Sumarwati, H. Fitriyani, F. M. Azhar Setiaji, M. Hasril Amiruddin, and S. Afiat Jalil, "Developing Mathematics Learning Media Based on E-Learning using Moodle on Geometry Subject to Improve Students' Higher Order Thinking Skills,” Int. J. Interact. Mob. Technol., vol. 14, no. 04, p. 182, Mar. 2020, https://doi.org/10.3991/ijim.v14i04.12731

[43] N. Tambunan and F. A. Batubara, "Gadget Utilization as a Source of Learning Students of Grade XII SMA Panca Budi Medan," International Journal of Research and Review, vol. 7, no. 4, pp. 524-547, 2020.

[44] T. Suryati, "The Effect of E-Learning Based on Schoology and Student Interest to Metacognitive Thinking Skill of Vocational High School Students in Archival Subject," International Journal of Research \& Review, vol. 6, no. 12, pp. 397-404, 2019.

[45] A. F. Umbit and M. S. Taat, "The Effects of Expectations and Satisfaction towards ELearning among Students," JMER, vol. 6, no. 9, pp. 603-611, Sep. 2016, https://doi.org/ 10.15341/jmer(2155-7993)/09.06.2016/004.

[46] S. M. Ross, G. R. Morrison, and D. L. Lowther, "Educational Technology Research Past and Present: Balancing Rigor and Relevance to Impact School Learning," Contemporary Educational Technology, vol. 1, no. 1, Mar. 2010, https://doi.org/10.30935/cedtech/5959.

[47] B. M. AlFawwaz, "Effect of Cloud Based Educational Applications in E-learning: Evidence from Jordan," Int. J. Interact. Mob. Technol., vol. 11, no. 4, p. 30, May 2017, https:// doi.org/10.3991/ijim.v11i4.6378. 
[48] E. Galy, C. Downey, and J. Johnson, "The Effect of Using E-Learning Tools in Online and Campus-based Classrooms on Student Performance," JITE:Research, vol. 10, pp. 209230, 2011, https://doi.org/10.28945/1503.

[49] C. Vitolo, Y. Elkhatib, D. Reusser, C. J. A. Macleod, and W. Buytaert, "Web technologies for environmental Big Data," Environmental Modelling \& Software, vol. 63, pp. 185-198, Jan. 2015, https://doi.org/10.1016/j.envsoft.2014.10.007.

[50] K. Kartimi, R. Y. Gloria, and A. Ayani, "Penerapan Pendekatan Keterampilan Proses Dalam Pengajaran Biologi Untuk Mengetahui Hasil Belajar Siswa Pada Pokok Bahasan Ekosistem Kelas VII Di SMPN 1 Talun," Scientiae Educatia: Jurnal Pendidikan Sains, vol. 2, no. 1, Art. no. 1, Apr. 2013, https://doi.org/10.24127/bioedukasi.v7i2.613

\section{Authors}

Hendri Prastiyono is a teacher at Senior High School Wachid Hasyim 2 Taman, Sidoarjo, Indonesia and was awarded best teacher from the Indonesian Ministry of Education and Culture. He is studying in a doctoral program in the Department of Geography Education, Faculty of Social Science, Universitas Negeri Malang, Indonesia. Fields of expertise include geography learning, multimedia, mobile learning, and outdoor learning. Orcid ID: 0000-0002-8833-2821.

Sugeng Utaya is a professor and researcher in the Department of Geography Education, Faculty of Social Science, Universitas Negeri Malang, Indonesia. Fields of expertise include physical geography, hydrology, and environmental geography. Orcid ID: 0000-0003-3239-5273, Scopus ID: 57205504005.

Sumarmi is a professor and researcher in the Department of Geography Education, Faculty of Social Science, Universitas Negeri Malang, Indonesia. Fields of expertise include environmental geography, geography learning, and environmental education based on local wisdom. Orcid ID: 0000-0002-3102-0376, Scopus ID: 57210109291.

I Komang Astina is an associate professor and researcher in the Department of Geography Education, Faculty of Social Science, Universitas Negeri Malang, Indonesia. Fields of expertise include social geography, gerontology, and tourism geography. Orcid ID: 0000-0002-6107-2652, Scopus ID: 57208471315.

Saiful Amin is a lecturer in the Department of Social Science Education, Faculty of Tarbiyah and Teacher Training, Universitas Islam Negeri Maulana Malik Ibrahim Malang, Indonesia. Saiful Amin is studying in a doctoral program in the Department of Geography Education, Faculty of Social Science, Universitas Negeri Malang, Indonesia. He is also a research assistant at the Faculty of Social Science, Universitas Negeri Malang, Indonesia. Fields of expertise include geography learning, education. and teacher training, and social studies education. Orcid ID: 0000-00015408-2898, Scopus ID: 57213147709.

Muhammad Aliman is a doctor and teacher at Public Senior High School $15 \mathrm{~Pa}-$ dang, Indonesia. Fields of expertise include geography learning, environmental education, local wisdom, and spatial thinking. Orcid ID: 0000-0001-9918-3991, Scopus ID: 57210109291.

Article submitted 2021-01-23. Resubmitted 2021-03-03. Final acceptance 2021-03-05. Final version published as submitted by the authors. 